\title{
The Role of Information Technology in Fintech Innovation: Insights from the New York City Ecosystem
}

\author{
Stanislav Mamonov ${ }^{(\bowtie)}$ \\ Montclair State University, Montclair, NJ 07030, USA \\ stanislav.mamonov@montclair.edu
}

\begin{abstract}
Fintech is an active area of innovation and a rapidly growing sector of the economy, yet relatively little is known about how information technology contributes to innovation in fintech. We draw on the business model canvas framework and we examine the role of information technology in the business models of leading fintech startups in the New York City fintech ecosystem. We find that information technology plays a key role across nearly all components of the business models, orchestrating resources and processes to efficiently deliver personalized financial services to customers. Focusing on the IT-enabled value propositions across the fintech startups in our sample, we find that the startups tend to emphasize low-cost offerings that may pose a threat to incumbent business models in financial services.
\end{abstract}

Keywords: Fintech $\cdot$ Innovation $\cdot$ Business model $\cdot$ Information technology

\section{Introduction}

Disruptive innovations are a common concern for established firms [11]. Disruptive innovations introduce significant changes in the value creation process within established industries by either developing new markets or changing the existing value creation networks [8]. In many cases, such innovations may initially target the less profitable segments of the market, but evolve into dominant business models within the respective industries [38].

Fintech, defined as design and delivery of financial products and services through technology [24], is one of the most active areas of startup innovation. Forecasts for the global fintech market suggest that global fintech revenues will reach $\$ 300$ billion by 2023 [27]. Despite the practical importance of the fintech market there has been relatively little research on how startups leverage technology in this market and how information technology (IT) may contribute to the disruption of traditional business models in financial services.

To address this gap in research, we draw on the business model canvas literature $[29,30]$ and we examine the key technology-enabled innovations offered by the leading fintech startups located in New York City. New York City is a global center of finance hosting the headquarters for JPMorgan Chase \& Co, Citigroup, Goldman Sachs, Morgan Stanley, AIG, and American Express among other financial institutions, 
offering an ideal ecosystem to support fintech development [18]. This study is a part of a broader research stream exploring the role of technology in innovation. Here, we seek to address the following research questions: (1) How does IT contribute to innovation in fintech? and (2) What types of IT-enabled innovations are likely to disrupt existing financial services? To address these questions, we focus on the leading startups in the NYC fintech ecosystem based on the funds raised from investors in the past 5 years and we examine how IT contributes to the value creation within each product or service offering. We also evaluate the likely disruptive impact of the IT-enabled innovations.

Our analysis reveals that information technology is deeply interwoven into nearly all components of the fintech startup business models in our sample. IT plays a dual role of serving as the customer facing artifact in service delivery, but it is also a key coordination mechanism that orchestrates all business processes within the respective companies. Focusing on value propositions offered by the fintech startups in our study, we find that the majority emphasizes low-cost alternatives to traditional financial services, thus posing a potential disruption threat to the incumbent firms in the respective markets.

\section{Empirical and Theoretical Background}

\subsection{The Role of Technology in Innovation}

The connection between technology and innovation is a rich area of research $[6,32,36]$ and a full review of this literature is beyond the scope of the current study. Here, we briefly review the key themes that are relevant to our work.

Information technology is broadly acknowledged as an important element of internal process optimization [28, 34], as well as new product and new service development [28]. Whereas much of the earlier work on the impact of IT investments focused on the macro level outcomes, e.g. firm survival and firm revenue [35], more recent research has shown that the effects of IT go beyond increasing operational efficiencies. Mithas et al. [28] have shown the IT investments increase new product and new service introductions, demonstrating that IT investments have a positive effect on innovation within established firms.

Open innovation, i.e. engagement of external parties in the innovation process $[5,13]$ has emerged as a dominant theme in the discussions on the role of IT in innovation more recently. Open innovation encompasses both supplier-side as well as customer-side innovation. Open source software emerged as a dominant paradigm in supplier-driven innovation [1, 22]. Value co-creation has similarly emerged as an important area in customer-driven product and service innovation [4, 17]. Several scholars suggested that information technologies fundamentally alter the innovation process and they require novel organizing logics designed to capitalize on the core benefits of digital technologies [20, 37].

\subsection{Fintech}

Although a number of competing definitions of fintech have been proposed, we adopt the following definition in our study. Fintech is defined as design and delivery of 
financial products and services through technology [24]. Financial services encompass a broad range of services that include payments, wealth management, lending, capital markets and insurance among others [23].

An economic analysis of financial services has revealed that despite digitization and adoption of novel technology-supported business services in finance, the industry as a whole has shown little in the way of increasing overall efficiency and the cost of financial intermediation remain stable over time at roughly $2 \%$ of GDP [31]. The perceived lack of efficiency in financial services industry has spurred many startups in the fintech domain and their efforts have generally focused on disintermediation and automation [7]. Industry surveys suggest that novel fintech offerings may be particularly appealing to young, high-income, high-value customers [11].

Although the research on fintech is just beginning to emerge, there have been several attempts to develop general taxonomies of fintech innovations. Focusing on the services offered by the companies, Lee and Shin [23] suggested that all fintech startups belong to one of the following categories: payments, wealth management, crowdfunding, lending, capital markets and insurance. Focusing on the technical capabilities, Gai et al. [12] proposed that technical innovations in fintech can be characterized as innovations in authentication and control, risk management, data usage, risk detection, and data storage and processing. Examining innovations in the insurance industry, Szopinski et al. [33] suggested that innovations fall into infrastructure, service or network promotion related categories.

Although prior research contains several fintech taxonomies [12, 23, 33], they do not address the question of how information technologies affects fintech business models. In the next section, we discuss the business model canvas framework [2, 39] that provides the theoretical foundation for the examination of the role of IT in fintech business model innovation in our study.

\subsection{Business Model Canvas and Business Model Disruptions}

Business model innovation has been long recognized as an important element of business strategy [2, 39]. Business model canvas emerged as a pragmatic framework focused on defining the key components of a business model with the goal of identifying opportunities for business model innovation [29, 30]. Business model canvas suggests that identification of the (1) key partners, (2) key activities, (3) value proposition, (4) customer relationships, (5) customer segments, (6) key resources and (7) distribution channels can lead to reassessment of the current state and identification of novel options within each of the components that can pave the way to business model innovation.

Disruptive innovation theory emerged from the observation that many dominant firms fell victim to innovations that the firms dismissed at the time of the innovation introduction [8]. For example, IBM famously dismissed the personal computer market opportunity early on [19], and the firm later had to play catchup to the early movers in the market. Christensen's theory of disruptive innovation [8] highlights the fact that ignoring innovative offerings in emergent markets often makes economic sense to the incumbent firms, thus highlighting a fundamental impediment to innovation within the incumbent firms. 
The focus of the current study is on understanding how fintech startups leverage IT to produce innovations within the components of the business models and to understand when such innovations may produce disruptions in the incumbent business models. In the next section, we discuss the methodology in our study.

\section{Methodology}

Methodologically, we take on a pragmatic stance that emphasizes the connection to the real world [16]. We follow a multi-case methodology [10] to assess and contrast observations across a theoretically based [15] sample of fintech startups.

\subsection{Sample Selection}

We relied on Crunchbase [9] to identify fintech startups headquartered in New York City. Crunchbase collates information on over 5000 startups across the globe in different sectors of the economy. We filtered Crunchbase listings for "fintech" as the category and "New York" as the headquarters location. We further limited our search to active startups that were founded in the period 2014-2019.

We obtained a list of fintech startups located in New York that includes 224 companies. Many of the startups on the list are in the early stages of development. $95 \%$ of the startups had received only a single round of financing and therefore the long-term prospects of these companies are less certain [3]. Historical trends suggest that less than $12 \%$ of VC investments lead to successful exits [14]. Because the focus of our analysis is on the effects of IT on business model innovation in fintech, we decided to focus our analysis on the startups that progressed to the second round of raising funding (typically a series B) and raised at least $\$ 20$ million dollars in total funding. The resultant list contains ten companies that collectively raised over $\$ 1.1$ billion.

\subsection{Analytical Methodology}

In our analysis on the role of technology in innovation we focused the role of technology in addressing the key components of the business model canvas. We examine the following questions within the analysis of each component [29, 30]:

\begin{tabular}{l|l}
\hline Value proposition & $\begin{array}{l}\text { What is the role of IT in the value proposition of each } \\
\text { company? }\end{array}$ \\
\hline $\begin{array}{l}\text { Customer segments and } \\
\text { distribution channels }\end{array}$ & $\begin{array}{l}\text { How does IT enable the company to address different } \\
\text { customer needs? } \\
\text { How does IT facilitate/enable different distribution channels? }\end{array}$ \\
\hline Key activities & $\begin{array}{l}\text { How is IT involved in the key activities associated with } \\
\text { value delivery? }\end{array}$ \\
\hline Key resources & $\begin{array}{l}\text { How is IT involved in the acquisition/development of key } \\
\text { resources associated with value creation/delivery? }\end{array}$ \\
\hline Key partners & $\begin{array}{l}\text { How is IT involved in managing relationships with key } \\
\text { partners? }\end{array}$ \\
\hline Revenue stream & What are the sources of revenue for the company? \\
\hline
\end{tabular}


To assess the key value proposition, customer segments and distribution channels, key activities, resources, partners and revenue streams, we reviewed the respective company web sites and news announcements. We used NVivo version 12 software to code the collected documents for the components of the business canvas model as well as the role of IT in the respective components.

\section{Results}

In our sample, we have startups offering a broad spectrum of fintech products and services that offer very different value propositions. Six of ten startups $(60 \%)$ in our sample are B2C companies offering insurance brokerage, equity trading, retirement planning, online banking, and real estate investment opportunities. One other startup offers consumer purchase financing, but it offers its service via partnerships with retailers, thus operating on a B2B/B2C model. Another startup developed a peer-topeer (P2P) money transfer services for consumers, but it sells its service to financial institutions that integrate the offering within their digital banking services. This is also an example of hybrid B2B/B2C business model. We find only one pure B2B startup in our sample that offers fraud prevention services to businesses.

The ten startups in our sample have collectively raised $\$ 1.175$ billion. The mean amount of funding raised is $\$ 117.5$ million and the median is $\$ 97.4$ million. Betterment, an online retirement planning service, has raised $\$ 275$ million putting it in the lead in terms of total fundraising. Venmo, a P2P payment service, raised only $\$ 26.2$ million.

Focusing on the whether the startup offerings represent low-cost alternatives to existing services or entirely new offerings, we find that nine of ten startups (90\%) in our sample are targeting lower price points in the respective markets, whereas only one startup - Cadre - is offering novel services. Cadre is a real estate investment platform that emerged in the wake of the JOBS Act passage that reduced regulator requirements in startup financing reporting and enabled equity crowdfunding as a practice [25]. The company is leveraging the regulatory changes to provide investors with novel investment opportunities that were previously only available to accredited investors [25]. The results are summarized in Table 1 below.

Table 1. Startup value proposition, business model type, market focus and funding raised.

\begin{tabular}{l|l|l|l|l}
\hline Startup & Value proposition & $\begin{array}{l}\text { Market } \\
\text { focus }\end{array}$ & $\begin{array}{l}\text { Model } \\
\text { type }\end{array}$ & $\begin{array}{l}\text { Funding, } \\
\$ \text { mil }\end{array}$ \\
\hline Policygenius & $\begin{array}{l}\text { The online service provides an } \\
\text { opportunity for insurance seekers to } \\
\text { compare policy premiums across } \\
\text { several providers and select the best } \\
\text { option }\end{array}$ & L & B2C & 51.1 \\
\hline Stash & $\begin{array}{l}\text { The online platform offers low-cost } \\
\text { equity trading for individual } \\
\text { investors - a basic account costs } \\
\text { \$1/month }\end{array}$ & L & B2C & 78.75 \\
\hline
\end{tabular}


Table 1. (continued)

\begin{tabular}{|c|c|c|c|c|}
\hline Startup & Value proposition & $\begin{array}{l}\text { Market } \\
\text { focus }\end{array}$ & $\begin{array}{l}\text { Model } \\
\text { type }\end{array}$ & $\begin{array}{l}\text { Funding, } \\
\$ \text { mil }\end{array}$ \\
\hline Bread & $\begin{array}{l}\text { The IT-based platform enables } \\
\text { online retailers to offer purchase } \\
\text { financing to their customers }\end{array}$ & $\mathrm{L}$ & $\mathrm{B} 2 \mathrm{~B} / \mathrm{B} 2 \mathrm{C}$ & 140.3 \\
\hline Riskified & $\begin{array}{l}\text { The IT-based platform offers fraud } \\
\text { prevention services in B2B } \\
\text { transactions }\end{array}$ & $\mathrm{L}$ & $\mathrm{B} 2 \mathrm{~B}$ & 63.7 \\
\hline Betterment & $\begin{array}{l}\text { The online service offers low-cost } \\
\text { retirement planning for individual } \\
\text { investors }\end{array}$ & $\mathrm{L}$ & $\mathrm{B} 2 \mathrm{C}$ & 275 \\
\hline $\mathrm{N} 26$ & $\begin{array}{l}\text { An online bank offers a streamlined } \\
\text { list of services to clients }\end{array}$ & $\mathrm{L}$ & $\mathrm{B} 2 \mathrm{C}$ & 212.8 \\
\hline TransferWise & $\begin{array}{l}\text { An online service that offers lower- } \\
\text { cost international wire transfers to } \\
\text { individual consumers }\end{array}$ & $\mathrm{L}$ & $\mathrm{B} 2 \mathrm{C}$ & 116 \\
\hline Cadre & $\begin{array}{l}\text { An online service that provides } \\
\text { access to high quality real estate } \\
\text { investment opportunities for } \\
\text { individual investors }\end{array}$ & $\mathrm{N}$ & B2C & 133 \\
\hline CommonBond & $\begin{array}{l}\text { An online service that offers lower } \\
\text { interest rates on education loans }\end{array}$ & $\mathrm{L}$ & $\mathrm{C} 2 \mathrm{C}$ & 78.6 \\
\hline Venmo & $\begin{array}{l}\text { A service that enables } \mathrm{P} 2 \mathrm{P} \\
\text { payments among individual } \\
\text { financial services users }\end{array}$ & $\mathrm{L}$ & $\mathrm{B} 2 \mathrm{~B} / \mathrm{C} 2 \mathrm{C}$ & 26.2 \\
\hline
\end{tabular}

L- low cost focus, $\mathrm{N}$ - new market focus

In the next step of the analysis, we examined the role of IT in (1) managing relationships with different customer segments, (2) management of distribution channels, (3) support key activities associated with value delivery, (4) provisioning and managing key resources required for product/service delivery, (5) management of relationships with key partners. We also evaluated the key revenue streams for each startup.

\subsection{IT in Customer Segmentation and Service Delivery}

Eight of ten startups in our sample offer online B2C services. It is not surprising then to find that IT plays a key role in service delivery and customer segmentation. IT systems, commonly a combination of web and mobile applications as well as backend services, are the key artifacts that customers interact with. Customer facing systems also facilitate customer segmentation, i.e. identification of customer groups with distinct needs. For example, PolicyGenius assists its customers in finding and evaluating available insurance policies and associated costs in different categories of insurance: home, life, auto, etc. The segmentation based on the insurance needs is seamlessly implemented on 
the site. Different customer segments navigate the evaluation paths setup to fit the specific insurance needs.

\subsection{IT Function in Key Activities Associated with Service Delivery}

Information technology uniformly plays a key role in automating the key business processes within each startup. For example, the trading platform Stash automates account setup for its customers and it supports efficient workflow on the backend associated with anti-money laundering (AML) and know-your-customer (KYC) regulations. We find similar patterns of front-facing automation and standardization of back-office operations across other B2C platforms in our sample.

The firms operating on the hybrid B2B/B2C models wherein the startups are providing financial services to individual consumers, but service delivery requires integration with business partners, solve the increasing channel complexity with encapsulation of the service-related activities in the IT-systems that are integrated with business partners' systems. Bread, for example, integrates with online retailers to offer purchase financing for consumers. Venmo integrates with financial institutions and provides seamless support for financial transfers among bank account holders who may not even be aware of Venmo's role in the process.

\subsection{IT in Coordination/Development of Key Resources}

Focusing on the role of technology in the development and coordination of key resources, we find that the IT systems themselves become the singular most important resource for each of the startups in our dataset. The IT systems encompass the customer-interfacing digital artifacts for B2C firms. The IT systems also encapsulate the business logic that underpins the operations of all firms in our sample.

\subsection{IT in Management of Partner Relationships}

We find that several of the startups in our sample are critically dependent on their partners for the key resources required for service delivery. For example, an online only bank N26 is critically dependent on its partnership with Mastercard that enables N26 to offer its customers an ATM card that operates across the Mastercard's Maestro platform. N26 leverages IT systems to assure seamless integration of its online banking services with the Maestro network so that its customers can have access to the funds kept at the bank. TransferWise, an online cross-border payment service, is similarly dependent on the Mastercard network in the execution of the international money transfers. TransferWise similarly employs IT systems to assure seamless integration between its web service and the Maestro payment network.

We find several other types of dependencies on IT services for integration with the key partners for service delivery. Riskified, a B2B fraud prevention service is dependent on third-party data in building its risk models. Stash, an online trading platform, is critically dependent on using IT services to connect with exchanges, clearing and settlement partners to assure proper execution and settlement of customer trades. 


\subsection{Revenue Models}

We find startups commonly inherit business models from the respective industries in which they operate. For example, PolicyGenius collects referral fees for the insurance policies that customers purchase through the service. Betterment, an investment and retirement planning platform, charges account fees and transaction fees. Riskified offers its service on the software-as-a-service (SaaS) model to business customers and it charges integration and usage fees.

We do find several more aggressive revenue model stances among the startups in our sample. Stash, for example, eschews trading account fees in contrast to many traditional brokers. Similarly, N26, an online bank, offers free accounts and free otherinstitution ATM use, presumably subsidizing these services from investment revenues. Table 2 summarizes the analysis on the role of IT across the key elements of the business models within the business model canvas framework.

Table 2. The role of IT in customer service delivery, key activities, managing relationships with key partners and revenue stream.

\begin{tabular}{|c|c|c|c|c|c|}
\hline Startup & $\begin{array}{l}\text { Customer } \\
\text { segment/distribution }\end{array}$ & Key activities & Key resources & Key partners & $\begin{array}{l}\text { Revenue } \\
\text { stream }\end{array}$ \\
\hline Policygenius & $\begin{array}{l}\text { The IT platform } \\
\text { offers services } \\
\text { directly to anyone } \\
\text { looking for life, } \\
\text { disability, auto and } \\
\text { homeowner's } \\
\text { insurance }\end{array}$ & $\begin{array}{l}\text { The IT platform } \\
\text { supports lead } \\
\text { generation and it } \\
\text { automates the } \\
\text { early stages in } \\
\text { the lead } \\
\text { screening } \\
\text { process }\end{array}$ & $\begin{array}{l}\text { The IT platform } \\
\text { supports } \\
\text { relationships } \\
\text { with insurers and } \\
\text { clients }\end{array}$ & $\begin{array}{l}\text { The IT platform } \\
\text { manages } \\
\text { relationships with } \\
\text { life, disability, } \\
\text { auto and } \\
\text { homeowner's } \\
\text { insurance } \\
\text { providers }\end{array}$ & $\begin{array}{l}\text { Commissions } \\
\text { on purchased } \\
\text { insurance } \\
\text { policies }\end{array}$ \\
\hline Stash & $\begin{array}{l}\text { The IT platform } \\
\text { provides a trading } \\
\text { platform to value- } \\
\text { conscious traders }\end{array}$ & $\begin{array}{l}\text { The IT platform } \\
\text { facilitates all } \\
\text { aspects of the } \\
\text { online investing } \\
\text { services offered } \\
\text { by the company }\end{array}$ & $\begin{array}{l}\text { The IT platform } \\
\text { provides a full- } \\
\text { service trading } \\
\text { platform }\end{array}$ & $\begin{array}{l}\text { The IT platform } \\
\text { supports } \\
\text { relationships with } \\
\text { partners that } \\
\text { provide account } \\
\text { servicing, trade } \\
\text { execution and } \\
\text { clearing }\end{array}$ & $\begin{array}{l}\text { Trading } \\
\text { rebates from } \\
\text { exchanges }\end{array}$ \\
\hline Bread & $\begin{array}{l}\text { The IT platform } \\
\text { provides integration } \\
\text { with online retailers } \\
\text { as a conduit to } \\
\text { individual } \\
\text { consumers }\end{array}$ & $\begin{array}{l}\text { The IT platform } \\
\text { enables purchase } \\
\text { financing for } \\
\text { consumers }\end{array}$ & $\begin{array}{l}\text { The IT platform } \\
\text { offers } \\
\text { integration, } \\
\text { credit scoring } \\
\text { and financing } \\
\text { management }\end{array}$ & $\begin{array}{l}\text { The IT platform } \\
\text { manages } \\
\text { relationships with } \\
\text { financial partners } \\
\text { who are a source } \\
\text { of capital }\end{array}$ & $\begin{array}{l}\text { Interest and } \\
\text { fees on } \\
\text { financed } \\
\text { purchases }\end{array}$ \\
\hline Riskified & $\begin{array}{l}\text { The IT platform } \\
\text { integrates with } \\
\text { enterprise customer } \\
\text { workflows }\end{array}$ & $\begin{array}{l}\text { The IT provides } \\
\text { a platform for } \\
\text { risk assessment } \\
\text { in B2B } \\
\text { transactions }\end{array}$ & $\begin{array}{l}\text { The IT platform } \\
\text { encapsulates } \\
\text { proprietary data } \\
\text { and risk } \\
\text { modeling } \\
\text { algorithms }\end{array}$ & $\begin{array}{l}\text { The IT platform is } \\
\text { a self-contained } \\
\text { offering, however } \\
\text { it is dependent on } \\
\text { third-party data for } \\
\text { service delivery }\end{array}$ & $\begin{array}{l}\text { SaaS } \\
\text { licensing }\end{array}$ \\
\hline
\end{tabular}


Table 2. (continued)

\begin{tabular}{|c|c|c|c|c|c|}
\hline Startup & $\begin{array}{l}\text { Customer } \\
\text { segment/distribution }\end{array}$ & Key activities & Key resources & Key partners & $\begin{array}{l}\text { Revenue } \\
\text { stream }\end{array}$ \\
\hline Betterment & $\begin{array}{l}\text { The IT platform } \\
\text { provides direct } \\
\text { access to budget- } \\
\text { conscious } \\
\text { consumers looking } \\
\text { for retirement } \\
\text { planning }\end{array}$ & $\begin{array}{l}\text { The IT platform } \\
\text { provides } \\
\text { retirement } \\
\text { planning }\end{array}$ & $\begin{array}{l}\text { The IT platform } \\
\text { is the core asset } \\
\text { of the company, } \\
\text { it provides } \\
\text { financial } \\
\text { management } \\
\text { services for } \\
\text { clients }\end{array}$ & $\begin{array}{l}\text { The IT platform } \\
\text { streamlines } \\
\text { relationships with } \\
\text { investment funds } \\
\text { that are the key } \\
\text { partners to the } \\
\text { platform }\end{array}$ & $\begin{array}{l}\text { Account } \\
\text { management } \\
\text { and trading } \\
\text { fees }\end{array}$ \\
\hline $\mathrm{N} 26$ & $\begin{array}{l}\text { The IT platform } \\
\text { provides direct } \\
\text { access to online } \\
\text { banking to } \\
\text { technology-forward } \\
\text { consumers }\end{array}$ & $\begin{array}{l}\text { The IT platform } \\
\text { provides online } \\
\text { banking services }\end{array}$ & $\begin{array}{l}\text { IT infrastructure } \\
\text { is the core asset } \\
\text { that supports } \\
\text { service delivery } \\
\text { to clients }\end{array}$ & $\begin{array}{l}\text { The IT platform } \\
\text { integrates with } \\
\text { Mastercard to } \\
\text { support the service } \\
\text { offerings }\end{array}$ & $\begin{array}{l}\text { Investment of } \\
\text { customer } \\
\text { funds }\end{array}$ \\
\hline TransferWise & $\begin{array}{l}\text { The IT platform } \\
\text { provides a lower- } \\
\text { cost option for } \\
\text { international funds } \\
\text { transfer }\end{array}$ & $\begin{array}{l}\text { The IT platform } \\
\text { facilitates cross- } \\
\text { border financial } \\
\text { transfers }\end{array}$ & $\begin{array}{l}\text { The IT platform } \\
\text { is the core asset } \\
\text { of the company }\end{array}$ & $\begin{array}{l}\text { The IT platform } \\
\text { integrates with } \\
\text { Mastercard to } \\
\text { support the service } \\
\text { offerings }\end{array}$ & Forex fees \\
\hline Cadre & $\begin{array}{l}\text { The IT platform } \\
\text { provides accredited } \\
\text { investors with } \\
\text { access to real estate } \\
\text { investment } \\
\text { opportunities }\end{array}$ & $\begin{array}{l}\text { The IT platform } \\
\text { supports the full } \\
\text { life cycle of real } \\
\text { estate investment } \\
\text { management }\end{array}$ & $\begin{array}{l}\text { The IT platform } \\
\text { streamlines deal } \\
\text { flow acquisition } \\
\text { and due } \\
\text { diligence }\end{array}$ & $\begin{array}{l}\text { The IT platform } \\
\text { integrates with } \\
\text { Goldman Sachs. } \\
\text { GS provides a } \\
\text { source of } \\
\text { financing }\end{array}$ & $\begin{array}{l}\text { Fees and } \\
\text { interest on } \\
\text { investments }\end{array}$ \\
\hline CommonBond & $\begin{array}{l}\text { The IT platform } \\
\text { provides students } \\
\text { with lower-cost } \\
\text { educational loan } \\
\text { options }\end{array}$ & $\begin{array}{l}\text { The IT platform } \\
\text { supports C2C } \\
\text { education } \\
\text { lending }\end{array}$ & $\begin{array}{l}\text { The platform } \\
\text { that encapsulates } \\
\text { loan } \\
\text { underwriting is } \\
\text { the core asset of } \\
\text { the company }\end{array}$ & $\begin{array}{l}\text { The IT platform } \\
\text { streamlines } \\
\text { relationships with } \\
\text { institutional } \\
\text { participants on the } \\
\text { platform that } \\
\text { provide capital }\end{array}$ & $\begin{array}{l}\text { Transaction } \\
\text { fees }\end{array}$ \\
\hline Venmo & $\begin{array}{l}\text { The IT platform } \\
\text { targets financial } \\
\text { institutions and } \\
\text { enables P2P } \\
\text { payments for } \\
\text { individual } \\
\text { customers }\end{array}$ & $\begin{array}{l}\text { The IT platform } \\
\text { enables P2P } \\
\text { payments among } \\
\text { individual } \\
\text { banking } \\
\text { customers }\end{array}$ & $\begin{array}{l}\text { The IT platform } \\
\text { and the } \\
\text { relationships } \\
\text { with financial } \\
\text { institutions are } \\
\text { the core assets of } \\
\text { the company }\end{array}$ & $\begin{array}{l}\text { The IT platform } \\
\text { provides } \\
\text { integration with } \\
\text { the financial } \\
\text { institutions that } \\
\text { are clients }\end{array}$ & $\begin{array}{l}\text { Transaction } \\
\text { fees }\end{array}$ \\
\hline
\end{tabular}

\section{Discussion}

\subsection{The Contribution of IT to Innovation in Fintech}

Our analysis reveals that information technology plays a key role across all components of the business models in fintech firms. IT plays a central role in value proposition formulation across all firms in our sample. IT systems developed by the startups encompass business process logic that underpins the core value creation by the respective companies. This is the case for firms in the $\mathrm{B} 2 \mathrm{C}$ and $\mathrm{B} 2 \mathrm{~B} / \mathrm{B} 2 \mathrm{C}$ startups 
where the IT systems are the focal points of contact with customers. This is also the case in the B2B scenario where the systems deliver value to business partners.

IT systems that are typically developed by startups as layered architectures with web and mobile frontend components, afford a direct channel to end customers. The direct route to end customers is consistent with the general role of technology in the disintermediation trend in fintech innovation that has been noted in prior research [7]. But the IT systems do more than just establish a direct route to end customers, the IT systems also support customer segmentation and personalization. The online insurance, equity trading, wealth management and banking service startups are in a unique position to elicit individual customer preferences and provide service personalization for each individual client through automated segmentation and personalization algorithms.

Across all startups in our sample, the IT systems also perform a key resource and process coordination function. The systems encapsulate and automate business processes, e.g. account application processes, they also provide seamless integration with partner systems where such integration is vital to service delivery, e.g. in the case of online banking and wire transfer services. By the virtue of encapsulating the core business processes and key partner relationships, the IT systems developed by fintech startups become the focal assets that support resource coordination that create value for the customers. In other words, information technology is interwoven into all elements of the fintech business model.

\subsection{Potential for Disruptive Innovation}

In his discussion of disruptive innovations, Christensen noted that disruptive innovations can emerge from low-cost offerings, focus on distinct customer segments, introduction of novel technologies and regulatory changes [8]. In our sample, Cadre exemplifies the case of disruptive innovation brought about by regulatory changes. Cadre offers real estate investment opportunities that were not available to investors prior to the passage of the JOBS Act [26].

We find that all other startups in our dataset focus on cost savings as the primary point of differentiation vis-à-vis traditional financial service providers. For example, the insurance broker PolicyGenius promises savings on the insurance policies. The online bank N26 offers free banking account and no ATM fees. The online trading platform Stash offers free equity trading. These offerings do put pressure on the traditional revenue streams in financial services. For example, Wall Street Journal recently reported erosion in the trading commission income across financial institutions offering equity trading that has been driven by online trading platforms offering free equity trading [21].

\section{Conclusion}

Fintech is a rapidly growing area of practice that is expected to reach $\$ 300$ billion in revenues by 2023 [27], yet relatively little is known about how fintech startups leverage technology for innovation. To address this gap in research, we examined the leading 
startups in the New York City fintech ecosystem that have collectively raised over $\$ 1.1$ billion in funding. We drew on the business model canvas framework and we examined how the startups leverage technology across their business model components. We find that technology platforms form the core of the innovative service offerings developed by the startups in our dataset. Further, we find that startups use low-price offering as the dominant strategy for disrupting the existing financial services markets. These observations provide empirical support for the theoretical arguments that call for the reexamination of the organizational logics underlying technology-driven innovation [36].

\section{References}

1. Agerfalk, P., Fitzgerald, B.: Outsourcing to an unknown workforce: exploring opensourcing as a global sourcing strategy. MIS Q. 32(2), 385-409 (2008)

2. Amit, R., Zott, C.: Creating value through business model innovation. MIT Sloan Manag. Rev. 53(3), 41 (2012)

3. CB Insights: Venture Capital Funnel Shows Odds of Becoming a Unicorn Are About $1 \%$. CB Research Briefs (2018). https://www.cbinsights.com/research/venture-capital-funnel-2/

4. Chen, L., Marsden, J.R., Zhang, Z.: Theory and analysis of company-sponsored value cocreation. J. Manag. Inf. Syst. 29(2), 141-172 (2012)

5. Chesbrough, H.: Open Innovation: The New Imperative for Creating and Profiting from Technology. Harvard Business Press, Boston (2006)

6. Chesbrough, H.: Business model innovation: opportunities and barriers. Long Range Plan. 43(2-3), 354-363 (2010)

7. Chiu, H.: Fintech and disruptive business models in financial products, intermediation and markets- policy implications for financial regulators. J. Technol. Law Policy 21(1), 55-112 (2016)

8. Christensen, C.M.: The Innovator's Dilemma: When New Technologies Cause Great Firms to Fail. Harvard Business School Press, Boston (1997)

9. Crunchbase: Crunchbase (2019). https://www.crunchbase.com/

10. Eisenhardt, K.M., Graebner, M.E.: Theory building from cases: opportunities and challenges. Acad. Manag. J. 50(1), 25-32 (2007)

11. Ernst and Young: Who will disrupt the disruptors? J. Financ. Perspect. 3(3), 1-191 (2015)

12. Gai, K., Qiu, M., Sun, X.: A survey on FinTech. J. Netw. Comput. Appl. 103, 262-273 (2018)

13. Gassmann, O., Enkel, E., Chesbrough, H.: The future of open innovation. R\&D Manag. 40(3), 213-221 (2010)

14. Giot, P., Schwienbacher, A.: IPOs, trade sales and liquidations: modelling venture capital exits using survival analysis. J. Bank. Finance 31(3), 679-702 (2007)

15. Glasser, B.G., Strauss, A.L.: Theoretical sampling. In: Denzin, N. (ed.) Sociological Methods: A Sourcebook (Methodological Perspectives), pp. 106-114. Transaction Publishers (2006)

16. Goldkuhl, G.: Pragmatism vs interpretivism in qualitative information systems research. Eur. J. Inf. Syst. 21(2), 135-146 (2012)

17. Gummesson, E., Mele, C., Polese, F., Galvagno, M., Dalli, D.: Theory of value co-creation: a systematic literature review. Manag. Serv. Qual. 6, 643-683 (2014)

18. Subrahmanya, M.H.B.: Comparing the entrepreneurial ecosystems for technology startups in Bangalore and Hyderabad, India. Technol. Innov. Manag. Rev. 7(7), 47-62 (2017) 
19. Den Hartigh, E., Ortt, J.R., Van de Kaa, G., Stolwijk, C.C.M.: Platform control during battles for market dominance: the case of Apple versus IBM in the early personal computer industry. Technovation 48, 4-12 (2016)

20. Henfridsson, O., Lind, M.: Information systems strategizing, organizational subcommunities, and the emergence of a sustainability strategy. J. Strat. Inf. Syst. 23(1), 1128 (2014)

21. Intelligent Investor: Your Stock Trades Go Free but Your Cash Is in Chains. Wall Street Journal (2019)

22. Von Krogh, G., Haefliger, S.: Opening up design science: the challenge of designing for reuse and joint development. J. Strat. Inf. Syst. 19(4), 232-241 (2010)

23. Lee, I., Shin, Y.J.: Fintech: ecosystem, business models, investment decisions, and challenges. Bus. Horiz. 61(1), 35-46 (2018)

24. Leong, C., Tan, B., Xiao, X., Tan, F.T.C., Sun, Y.: Nurturing a FinTech ecosystem: the case of a youth microloan startup in China. Int. J. Inf. Manag. 37(2), 92-97 (2017)

25. Mamonov, S., Malaga, R.: Success factors in Title III equity crowdfunding in the United States. Electron. Commer. Res. Appl. 27, 65-73 (2018)

26. Mamonov, S., Malaga, R.: Success factors in Title II equity crowdfunding in the United States. Venture Cap. 21(2-3), 223-241 (2019)

27. MarketWatch: Fintech Market: Industry Outlook, Size \& Forecast 2018-2023. MarketWatch (2019). https://www.marketwatch.com/press-release/fintech-market-industry-outlook-sizeforecast-2018-2023-2019-07-15

28. Mithas, S., Tafti, A., Bardhan, I., Goh, J.M.: Information technology and firm profitability: mechanisms and empirical evidence. MIS Q. 36(1), 205-224 (2012)

29. Osterwalder, A.: The business model ontology - a proposition in a design science approach. Business Doctor, pp. 1-169 (2004)

30. Osterwalder, A., Pigneur, Y.: Business Model Generation: A Handbook for Visionaries, Game Changers, and Challengers. Wiley, Hoboken (2010)

31. Philippon, T.: The FinTech opportunity. NBR Work. Pap. 3(1), 1-217 (2016)

32. Rogers, E.M.: Elements of diffusion. In: Diffusion of Innovations, vol. 5, no. 1.38 (2003)

33. Szopinski, D., Schoormann, T., John, T., Knackstedt, R., Kundisch, D.: Software tools for business model innovation: current state and future challenges. Electron. Markets, 1-26 (2019). https://doi.org/10.1007/s12525-018-0326-1

34. Wade, M.R.: The formation and value of IT-enabled resources: antecedents and consequences of synergistic relationships. MIS Q. 34(1), 163-183 (2010)

35. Weill, P.: The relationship between investment in information technology and firm performance: a study of the valve manufacturing sector. Inf. Syst. Res. 3(4), 307-333 (1992)

36. Yoo, Y.: The tables have turned: how can the information systems field contribute to technology and innovation management research? J. Assoc. Inf. Syst. 14(5), 4 (2012)

37. Yoo, Y., Henfridsson, O., Lyytinen, K.: The new organizing logic of digital innovation: an agenda for information systems research. Inf. Syst. Res. 21(4), 724-735 (2010)

38. Yu, D., Hang, C.C.: A reflective review of disruptive innovation theory. Int. J. Manag. Rev. 12(4), 435-452 (2010)

39. Zott, C., Amit, R., Massa, L.: The business model: recent developments and future research. J. Manag. 37(4), 1019-1042 (2011) 